\title{
Speculation between Proponents and Opponents
}

\author{
Rafic Yunus Al-Masri \\ Islamic Economics Research Centre \\ King Abdul Aziz University, Jeddah, Saudi Arabia
}

\begin{abstract}
Speculation on prices is the essence of the stock market, the same as interest is the essence of the commercial banks business. As such, the study of speculation should take priority to the elaborate study of contracts in the financial markets, e.g. short selling, options, futures and margin-purchasing.

The paper reviews the opponent's, as well as the supporter's opinions of speculation, and concludes that speculation is a form of gambling, whereby a minority wins what the majority of investors lose. This leads to departure of stock prices from the real value of the commodity or financial paper, thus precipitating price volatility. Actually, commodities and financial papers are not the objective of speculation. What is intended is profiting from stock prices differences. So, the question arises whether it is advisable to prohibit deferred contracts so that the stock market is cleared from speculation, allowing real investment to prevail.
\end{abstract}

If interest is the "guiding soul" of conventional banks, so is speculation for the stock markets. In studying the stock market processes, it is preferable to start with speculation before moving on to other details like short selling, options, futures and margin trading. Accordingly, the study of speculation falls under the stock market's generalities, while, contracts are considered within its specifics. Thus, we must consider speculation when studying stock-market transactions; otherwise lawful rulings would be unsound. Besides, studying speculation is an essential introduction for studying stock market transactions and it facilitates attaining the fiqhi (jurisprudential) rulings regarding such dealings.

This issue appears to be more important in the Arab and Islamic countries, of which some already have stock markets that need to be activated, while others have no stock markets at all, and intend to establish them. In both cases, the truth about speculation needs to be revealed. Since this issue is controversial among both Westerners and Muslims, one would hope that such controversy in an Islamic context, is not a mere echo of the Western one. 


\section{Definition of Speculation}

A number of definitions of speculation used in professional writings are mentioned hereafter. However, most of them, as will be noticed, are either incomplete, ambiguous or misleading. The reader would be able to realize the meaning of ambiguity as we go further in the discussion. These definitions are as follows:

- Speculation is the prediction of a profit opportunity to benefit from, and of a loss probability to avoid.

- Speculation is to buy or sell, to benefit from price differentials that result from the expectation of change in the stock values.

- Speculation is a big venture aiming at attaining gains. Its prime goal is to increase capital rather than dividends from shares.

- Speculation is to buy or sell with the aim of increasing capital gains from the natural price differences rather than obtaining regular revenue profits.

- Speculation is a buying or selling process followed by other reverse process, based on justified information, aiming at benefiting from the natural differences in prices.

- Speculation is buying or selling in the present, with the hope of buying or selling in the future when a change in prices occurs.

- Speculation is to buy, aiming at selling at a higher price or to sell to compensate for what was sold at a lower price.

- Speculation is a fake buying or selling, not with the aim of investment, but rather with the aim of benefiting from changes in the very short-term of the stock market value. This occurs when a big difference takes place between the stock market price on one side and the nominal or book-value (the real value) on the other. (Mohiuddin, 1415H, p.482, and Suleiman, 1426H, 2: 672). In fact, the real value is different from the book-value and it is more appropriate to use in the definition.

- Speculation is a buying or selling process carried out by market experts to benefit from price changes (al-Mu'jam al-Wasit).

Speculation is a fake reverse process of selling and buying not aiming at physically exchanging commodities (no actual "commodity" is desired for itself). In reality, it aims at benefiting from natural or artificial price differences and capital gains if the predictions of price changes in the short-term proved to be true. No matter, this prediction comes out of information, experience and study or merely out of rumors, luck or even coincidence.

\section{The Difference between Speculation and Trade}

- The merchant possesses goods; whereas, the speculator does not. He only gets or pays the price differences (clearing). This non-possession of goods is a distinguished characteristic of speculation. Besides, in speculation, selling or buying is fake and reversed as the good in itself is unwanted. Samuelson (1985, pp. 214 and 215) says: "They (the speculators) are simply middlemen who are 
interested in buying cheap and selling dear. The last thing they want to see the wheat or hog truck roll up to their door (...). The speculators themselves may never touch a kernel of corn or a bag of cocoa, nor need know anything about storage, warehouse, or delivery. They merely buy and sell bits of paper".

- The merchant does not count upon price betting, while the speculator depends upon betting either through prediction or expectation. Some authors respond to this argument by saying that the merchant also makes a bet, if his bet is true, he profits, if not, he loses. However, betting in trade remains concerned with the commercial activity and is not isolated from it as in speculation.

- The merchant counts on price stability; whereas the speculator counts on price fluctuations.

- Price manipulation is more common in speculation than in commerce. This manipulation occurs through rumors and fake deals. Despite the fact that this manipulation could be common (with difference) to both the monopolist merchant and the monopolist speculator, yet, it is more a characteristic of monopoly rather than of speculation.

- One of the important points is that speculation causes prices to be far distant from goods or stocks' real prices and away from the real financial performance of the stock-issuing company. This leads to price increase despite having no purchase intention (najash). On the contrary, in commerce, the real and sell prices are close and relevant to each other.

- In trade, both the seller and the buyer win; whereas, in speculation, one of them wins what the other loses, which is known in the Western writings as 'Zero SumGames'. In addition, trade is productive while speculation is not, thus, the speculation's risk differs from that of commerce. Some people would argue that speculation is also productive in the sense that it transfers risks to those who are willing to undertake them and in this case these people specialize in undertaking risks. However, this argument may actually aim at embellishing speculation rather than revealing the truth about its hidden purposes.

\section{The Difference between Speculation and Investment}

An investor buys the stock and keeps it to get dividends. He may sell his stock, when needed, to attain a capital gain although this does not represent the normal case. On the other hand the speculator buys the stock to sell it in the short-term when the price increases, aiming at cashing-in a high and rapid capital gain.

Thus, investment is long-term, with relatively lower- risk and its return is more secure than speculation. While, speculation is short-term and is characterized with rapid gains and high risks. Accordingly, speculation differs from investment in its duration, the risk degree and the expected revenue. The speculator undertakes a high risk to attain the highest possible amount of capital gains in the shortest possible time. Whereas, the investor undertakes a low risk to acquire a reasonable dividends, while his expected capital gains from market prices' fluctuation comes in the second place. However, if a person wants to be an investor in the stock market, the speculators will transform his investment into speculation. 


\section{The Difference between Speculation and Gambling}

The proponents of speculation differentiate between speculation and gambling on the basis that speculation depends upon information, experience and study unlike gambling that leans merely on fortune and coincidence. Yet, some believe that there are two types of speculation:

- The first type depends upon experience. This type is few in number (speculation of big professionals).

- The second type which is more popular depends upon fortune (speculation of small amateurs).

Despite the differences between them, both types are considered speculation. Likewise, modern gambling could also depend upon information, experience and study.

The proponents of speculation believe that the gambler himself creates risks, while the speculator only transfers risks as he undertakes existing ones. On the other hand, the opponents of speculation believe that there is no difference between speculation and gambling, but rather it is a new version of it. They argue that in speculation as well as in gambling a few people gain huge and rapid fortunes while the majority loses and whatever is gained by the minority comes at the expense of the majority. In addition, the chances of the minority's making a profit is very small, very close to their chances of winning the lottery. Accordingly, they are more liable to loss in both cases. On the other hand, big speculators' profits are huge and guaranteed at the expense of small speculators who are being exploited in the stock market to act as its fuel and victims at the same time.

\section{The Proponents' Arguments}

- Speculation reduces price fluctuations so that when prices decrease, the speculators intervene and buy, this in turn limits the continued decrease due to the increased demand. Similarly, when the prices rise, they intervene through selling their shares, thus limiting the increase in price. Therefore, speculation works on stabilizing and rebalancing prices and narrowing the gaps between them. (al-Barbari, 2001, p.282).

- Speculation reduces the merchants' risks as it either realizes profits or minimizes losses through_reverse or compensating deals.

- Speculation activates the stock market as it encourages the circulation of large amounts of stocks or goods. This in turn flourishes the stock market, enlarges its role and helps in providing liquidity easily and rapidly. Thus, the speculators are added to the investors in the stock market. They activate the stock market with their rapid and multiple speculations. Accordingly, there are three types of deals or contracts: spot contracts, forward contracts and speculative contracts, so that if the speculation contracts were cancelled, the stock market activity would weaken. Similarly, if the forward contracts were cancelled, the stock market activity will get weaker as debts multiply activity and likewise the speculations greatly multiply it. Thus, if speculation was supported by debts or credit, the stock market would increase more and more. 
- The speculator seeks to obtain a personal profit and there is nothing wrong with that, as profit represents the main cause for establishing any economic project and it is the main incentive for any production process. Profit always depends upon price changes and fluctuations so that no economic or commercial project can avoid speculation in which you can buy with the least possible price and sell with the highest possible one. Consequently, no capital investment could be totally speculation-free.

\section{The Opponents Arguments}

- Speculation aggravates price fluctuations as it originally relies on such fluctuations and it finds no room if the prices stayed stable. In speculation, prices rise and drop to economically unjustified levels regardless of the real value of the stock or good and of the actual performance of the stock-issuing company. Thus, speculation is an artificial heating up and an unwanted additional parasite activity.

- The brokers and the well-informed speculators are the ones who benefit from the intense heat produced by speculation. On the contrary, this heat brings no benefit to the public but rather it is a source of harm to them as it is an attractive but intriguing activity.

- Speculation does not differ from gambling but rather it is one of its modern forms. In fact, stock markets are nothing but dubious houses protected by law or gambling casinos where people gain unbelievable fortunes at a wink and at the same time it witnesses overwhelming losses in seconds causing disastrous impacts like bankruptcy, family disputes, divorce, heart attacks and sudden deaths. So, it is more like lottery where the minority of dominant organizers wins while the majority masses lose. In other words, the small speculators fall as an easy prey in the clutches of the stock markets' tycoons. Such dominant tycoons are very powerful and they are aware of all the stock market's secrets and they are associated with the top government leaders. In addition, they work together under cover using intrigues, plots and rumors and they control media. They also exploit credit to support speculation and they affect heated and wild speculations to the extent that speculation becomes more like a Crazy Market. Some others argued that the people's movements in the stock market look like they are working under a spell.

However, these movements could look very attractive but they are very intriguing at the same time as such tycoons own a lot of money that flow as fast as a wink from one place to the other. Sometimes such money causes a disastrous effect like the weapons of mass destruction as they ruin some countries' economy. The 24 hours modern electronic network increased further the intensity of these speculations as it offers a minute- per- minute price quotes and displays 375-purchase orders/second with a total of 2 billion process/day. This in turn increases the risks of turbulence and financial instability all over the world as such price quotes instantly spread to international stock markets directly causing a mania in all other stock markets.

- Speculation, gambling, betting and monopoly are all characteristics of Capitalism also known as 'Casino Capitalism'. It is noteworthy that the capitalist countries 
together with the multinational companies secretly commenced in setting up a multi-party investment agreement that was about to be signed in 1998 except for the NGOs' efforts in Europe and the United States that fought that agreement. An American society called "Public Citizen's Global Watch" unveiled this secret plot as its chairman "Lori Wallach" wrote an article about this issue in the French newspaper, Le Monde Diplomatique, in December 1998 under the title: "The World Declaration of Capital Rights". Such agreement could have allowed the gigantic monopolists and multinational companies to sue any government calling for compensating any harm caused by any policy or attitude that would negatively affect the accumulation of gains and wealth (al-Barbari, 2001, p.344).

- Speculation is associated with monopoly as there are big speculators who dominate goods or stocks and control them, thus converting speculation from a price prediction tool to price enforcing tool. Yet, who could punish these tycoons? They cannot be legally sued for this predomination (al-Barbari, 2001, p.317). Punishing small investors and speculators is very easy even if they do not deserve it, but punishing those tycoons is very difficult even if they deserve it. In addition, all the claims of competitiveness, transparency and equal information is only a camouflage for monopoly, secrecy and domination. People of authority are always using such words as "reformation", "competition" and "colonization" to refer to "corruption", "monopoly" and "occupation". They have even called destructive chaos "creative chaos"!

- If the reverse contracts known as deferred sales or 'inah sales are religiously forbidden (haram), even though they involve delivery of commodities, then how about the reverse contracts that do not involve any delivery or receipt of commodities (the commodity in itself is unwished-for)? So, what would be the lawful ruling regarding this issue especially if we bear in mind that it is considered an entire risk and it is not associated with trade? Since no mutual possession takes place in the stock market, then, the good is no longer important and it does not matter anymore if it is fungible or non-fungible good, suitable or non suitable for deferred contracts. In fact, the goods could be fake or symbolic like the indices and even the companies themselves could be a mere illusion.

- Gambling exists originally in playing games, yet, it could also be involved in selling, in other words, it is called gambling in playing games and gharar (deception) in selling. Likewise, in the stock market, speculation transforms selling into bets or fake contracts or rather games as they used to do in Jahiliyah (the era before Islam) such as hasah, mulamasah and munabadhah sales.

\section{The Moderate Opinion: Using Speculation without Excessiveness}

As it is commonly applied today, some economists argue that speculation is indispensable. According to their view, it has become like alcoholic beverages or table salt, a little of it could be good but having much of it is definitely harmful. Despite the fact that these items are not always favorable, yet, they must not be continually blamed as they have both good and bad aspects. Thus, if we want to have an active market, we could make use of it in a reasonable but not in an excessive way. (al-Ashqar, $1416 \mathrm{H}$, p.102, 106) 
It appears to me that speculation is not the kind of thing that we could limit it if we permitted it. It is not also one of the things like gharar that few of it is allowed but much of it is forbidden. However, speculation is more like gambling and betting rather than gharar. Besides, gharar is associated with real selling, while gambling is associated with playing games and sometimes with fake selling.

Some experts believe that it is hard to differentiate between speculation and gambling so they find excuses for those who blame speculation for all the misdeeds taking place in the stock market. (al Barbari, 2001, p. 279). Thus, hypothetically, although some of speculation might be permitted, yet, we have to forbid this small permitted amount, as it would be very difficult to limit speculation in the stock market to reasonable or acceptable levels only.

In his research, Kamali (1996, p.197) cited the hadith that says: "Do not sell what is not with you" and the hadith that forbids sale prior to taking possession and the hadith of debt clearance sale (bay' al kali' bi al kali'). He found that the first hadith refers to "sale of specified objects (a'yan)" rather than "fungible goods", thus, if it meant the ability to deliver, then this is already taking place in the stock market. The second hadith refers to food rather than other goods that could be sold by installments. The third hadith is a weak one as the Holy Qur'an allowed debt as showed in the clear-cut Qur'anic debt-verse. So, Kamali tried to purify the stock market's contracts from such forbidden acts but at the end he warned against excessive speculation and gharar. I find myself agreeing with him on the possibility of purifying this issue from all its forbidden aspects unlike the opinion of a number of researchers and figh organizations who think that this issue is already settled and needs no more investigation. It may also be allowable to close a deal based on 'arbun (a down-payment), to those who legalized 'arbun and extend that to stock-market transactions. However, that is not enough to legalize the whole process.

However, Kamali's research neither showed how we could protect the stock market from this excessiveness nor referred to the impact of speculation on the small speculators. He did not also discuss the effect of reverse contracts on heating up the stock market and how its prices jump up to unjustified economic levels, which are irrelevant to the real performance of the stock issuing companies. Thus, he overlooked the fact that in order to fully understand the stock market, you have to take into consideration the small speculators who represent the public majority and they act as the stock market's fuel and victims at the same time. In addition, you have also to keep in mind the violations protected or overlooked by laws and regulations that are nothing but a delusive nominal coverage like "anti-usury law" and "anti monopoly law".

Kamali was the only Shari'ah scholar who tried to investigate the permissibility of speculation and forward transactions in the stock market. One would wish that he can elaborate on the eight points raised below in the summary.

\section{Conclusion}

A Wall Street specialist wrote a book on the stock market showing in it the manipulation that is taking place in the stocks' prices and he published it under a pseudonym "Marchand Sage". There are, according to him, "intrigues, lethal 
competitions, tense lunch-time deals, high-stake gambles, the subterfuges, cover-ups, and huge payoffs that make Wall Street the greatest playground in the whole world" (Marchand Sage, as quoted by Chapra, 1985 p. 98).

What is the solution then? Shall we ban the stock market, speculation, reverse or forward transactions?

Some believe that the proposed solution is not to dispense of the stock market but rather to dispense of speculation (a stock market without speculation $=$ a more just and a more beneficial one, with less fuss and expenses). This could take place through canceling deferred contracts, a step already implemented in some stock markets (Muhieddin, 1415H, p. 93 and 520 and 561) and Chapra, 1985, p. 99). They argue that it is not enough to reduce these contracts through Central Bank's intervention in raising the monetary margins (the advanced cash installments) and limiting credit speculation. As for those who claim that speculation is the destiny of the stock market, according to them, nullifying speculation means nullifying the whole stock market.

How can we ban forward contracts when they are legitimately permitted by shari'ah? Islam permitted deferred payment (selling at installments) and allowed deferred delivery (salam), consequently, banning deferred contracts ultimately leads to banning something that is legitimately permitted. However, if we allowed the permitted deferred contracts, it would be difficult to ban the forbidden types of these contracts. Yet, it is worth remembering that what could not be legally banned, may be banned on religious bases.

\section{Summary}

- Speculation consists of reverse buying and selling processes resembling deferred or 'inah sales (the good is not important) in the fact that in both cases the dealer is not interested in the good itself at all.

- Speculation exceeds 'inah sales in the sense that it does not involve possession which means also that the good is unwanted.

- Speculation is a pure risk, separate from the commercial activity (it is a mere betting), so it is called in the Arab and Western laws.

- Speculation is a matter of price differences in which the small speculators depend only upon luck and coincidence, whereas, the big speculators use it as a mean for blackmailing, exploitation and becoming filthy rich at the cost of the general public. Thus, the outcome is that we have a few gaining party and a majority losing party, the minority gain is guaranteed while what is won by the majority is a mere lottery. What is gained by the minority is huge and what is lost by the majority is huge because in gambling what is lost by some is won by others: Zero Sum Game.

- Speculation is a dramatic and suspense heating up just as what is taking place in films and serials concealing underneath a lot of deception, manipulation and najash (false bidding in which the bidder wants others, rather than himself, to buy). Thus, now after the domination of Capitalism, gambling is concealed under the cover of cultural competitions, or of trade. It is a modern game having all the effects of fanciful and exciting artistic production. 
- Speculation leads to incorrect pricing of goods and stocks, as it neither reflects the company's performance nor the real value of stocks or goods.

- The solution is to have a stock market without speculation or reverse contracts lest we say a stock market without forward contracts. The suggestion of having a moderate speculation is unacceptable and impractical as it is no more than a trick hiding beneath theoretical regulations and false claims of information and experience. However, it is dominated by monopoly, deceit, rumors and misleading information aiming at deluding the public.

- Speculation, gambling and monopoly are the characteristics of Capitalism, even if capitalism pretends to stand against these practices. Capitalism either calls things with other names or mentions something theoretically and violates it in practice. It does not abide by religion or ethics unless they serve the tycoons even if this leads to the small investors' destruction. They want to impose upon us their system so that we lose the best we have and to receive the worst of what they have. This way they guarantee we stay behind in what they are already behind in.

- These methods that the "big-guys" propose are used to enable them to penetrate us and to strengthen their grip on us. Smaller investors should not fall into that trap and should not follow the "big-guys" and should not allow them to make money and power restricted to them. This manipulation of power and money by the "big-guys" will increase the tyranny of the more rich and more powerful, and result in the destruction of land and people. Instead of the affluent ones helping the needy, through this lottery and other means they are blackmailing them to the last penny (fils) they own.

\section{References}

\section{Arabic}

al-Ashqar, Ahmad Abd al-Fattah (1416H) "Nahwa Suq Maliyah Islamiyah" (Towards Islamic Stock Market) Islamic Economic Studies, Vol. 3, No.1.

al-Barbari (2001) al-Mumarasat Ghayr al-Mashru'ah fi Borasat al-Awraq al-Maliyah (The Unlawful Practices in Stock Markets), Markaz al-Musanadah al-Qanuniyah, Cairo.

Mohiuddin, Ahmad (1415H) Aswaq al-Awraq al-Maliyah fi al-Iqtisad al-Islami (The Stock Markets in Islamic Economics), Dallah Al-Baraka Group, Jeddah.

al-Suleiman, Mubarak (1426H) Ahkam al-Ta'amul fi al-Aswaq al-Maliyah al-Mu'asirah (Rules of Dealings in Modern Stock Markets), Dar Kunuz Ishbilyah, Riyadh.

\section{English}

Chapra, M.U., (1985) Towards a Just Monetary System, The Islamic Foundation, Leicester.

Kamali, Mohammad Hashim (1996) "Islamic Commercial Law: An Analysis of Futures", American Journal of Islamic Social Sciences, Vol. 13, No. 2.

Samuelson P. and Nordhause W. (1985) Economics, $12^{\text {th }}$ ed., McGraw Hill International, New York. 
المضاربة على الأسعار بين المؤيدين و المعارضين

$$
\begin{aligned}
& \text { رفيق يونس المصري } \\
& \text { مركز أبحاث الاقتصاد الإسلامي لي لون } \\
& \text { جامعة الملك عبدالعزيز - جدة - المملكة العربية السعودية }
\end{aligned}
$$

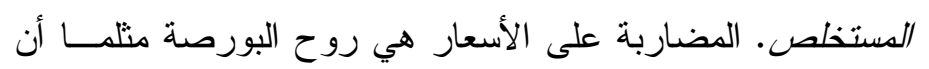

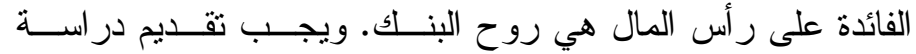

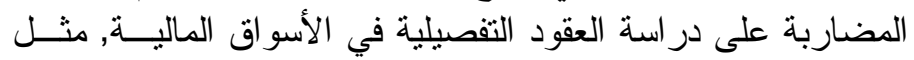

$$
\begin{aligned}
& \text { البيع القصير و الخيار ات و المستقبليات و الثر اء بالهامش. }
\end{aligned}
$$

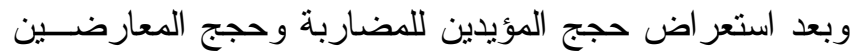

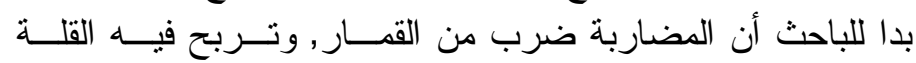

$$
\begin{aligned}
& \text { مايخسره الجمهور , وتكتتفها ألاعيب ومكايد, بحيث يكسب المباري المطلعون } \\
& \text { الكبار ويخسر الصغار , وتؤدي إلي أسعار تبتعد كثيرًا في ارتفاعها التها التها }
\end{aligned}
$$

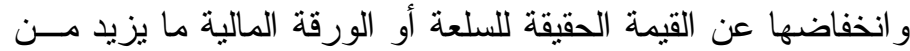

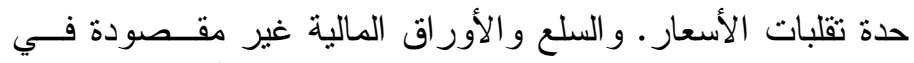

$$
\begin{aligned}
& \text { المضاربة, إنما المقصود هو المحاسبة على فروق الأسعار فقط. } \\
& \text { فهل يكون الحل بمنع العقود الآجلة لكي يتم تخليص البورصـــة } \\
& \text { من المضاربة, ويصفو الجو للاستثمار الحقيقي؟ }
\end{aligned}
$$

